\title{
Fieldwork during pandemic: Backyard bird survey and making student's biological field practice works
}

\author{
NURUL L. WINARNI ${ }^{1,2,}$, BHISMA G. ANUGRA ${ }^{1,2}$, SHANIA ANISAFITRI ${ }^{1}$, NABILLA N. KAUNAIN ${ }^{1}$, \\ DIMAS H. PRADANA ${ }^{1}$ \\ ${ }^{1}$ Department of Biology, Faculty of Mathematics and Natural Sciences, Universitas Indonesia. Jl. Prof. Dr. Sudjono D. Pusponegoro (Lingkar UI), Gd. E. \\ FMIPA UI, Kampus UI, Depok 16424, West Java, Indonesia. Tel.: +62-21-78849009, Fax.: +62-+62-21-78849010, "email: nwinarni@ gmail.com. \\ ${ }^{2}$ Research Center for Climate Change-Universitas Indonesia. Gd. Lab Multidisiplin FMIPA-UI Lt. 7, Kampus UI, Depok 16424, West Java, Indonesia
}

Manuscript received: 22 February 2021. Revision accepted: 22 March 2021.

\begin{abstract}
Winarni NL, Anugra BG, Anisafitri S, Kaunain NN, Pradana DH. 2021. Fieldwork during pandemic: Backyard bird survey and making student's biological field practice works. Biodiversitas 22: 1887-1894. The COVID-19 pandemic situations had forced universities to shutdown face-to-face lectures and change it to online teaching. This change had brought significant challenges to biological courses which need field practice in their syllabus and therefore field practice should be adjusted and innovative. During November-December 2020, we compared students' field practice from the Ornithology class to urban bird survey to evaluate whether the data collected by students can contribute to citizen science as well as to enhance field practice during online courses. We used point count methods to survey bird communities in urban environment in Jakarta and its satellite cities. We found that the students tended to observe the most abundant birds such as the cave swiftlet and Eurasian tree sparrow and missed unfamiliar species which were smallersized birds that use aerial and upper canopy. It was suggested that the data from field practice can also support citizen science when prioritized to common, abundance species. In addition, best practices for field practice were provided, emphasizing the independent field practice incorporating technology in which the results were communicated to the students. Hence, strengthening field practice for biological courses is important to support biodiversity conservation research and activities.
\end{abstract}

Keywords: Field practice, online courses, urban adapters, urban birds, urban exploiter

\section{INTRODUCTION}

The spread of new coronavirus infection COVID-19 worldwide in early 2020 has put a total change in many countries which affected human life and economics, including Indonesia. The COVID-19 has pushed some of the cities in Indonesia to apply partial lockdown. In terms of biodiversity conservation research and teaching, this partial lockdown has greatly affected the implementation of field research and teaching activities. The impact to research can be in the form of postponement of fieldwork, changed research topics to COVID-19 topics, as well as reduced funds to conduct research. Field scientists rely on physical laboratories reduced 30-40\% in their research time during pandemic compare to other disciplines (Myers et al. 2020). The situation can be worse for archipelagic countries such as Indonesia which has to put many research activities halted due to the increase of COVID-19 cases around the study area, limited traveling permit across the country or partial lockdown applied at different provinces, or even at districts. As to teaching activities, the university shutdowns all face-to-face lectures and move them to online format (Corlett et al. 2020) which brings problems to both lecturers and students such as internet costs, electricity, and even psychological costs (Murawiec and Tryjanowski 2020; Purwanto et al. 2020).

Lockdown in many countries during pandemic COVID19 may provide positive effects to wildlife and the environment. Air quality in Jakarta showed a decrease in pollutant levels (Pramana et al. 2020). The 'anthropause' or the dramatic slowdown in human activity caused by the pandemic has caused an increase in animal activity such as crossing roads or move out at a common time (Stokstad 2020). The less human activity in the urban parks was potential to increase sensitive species (Corlett et al. 2020). In urban areas in California, the reduction of motorcycle traffic, and noise have allowed songbirds to produce higher performance songs to fill up the empty noise space (Derryberry et al. 2020). Birdwatching is non-consumptive leisure activity that can be conducted outdoor (Randler et al. 2020) and the activity is important contribution to citizen science such as adding records of common birds (Winnasis et al. 2018). Not only important to citizen science, but birdwatching had also a positive effect on mental well-being, according to a study by Murawjec and Tryjanowski (2020) in Poland. Therefore, while work time has reduced, the slowdown of activity has brought field researchers and birdwatchers to do birding and bringing citizen science to public engagement (Burgess et al. 2017; Randler et al. 2020). Randler et al. (2020) reported a change in the birding behavior during this pandemic situation to a more localized birding - backyard birding. For example, a 16-year-old birdwatcher in Indonesia virtually invited 182 children aged 6-14 around Jakarta to learn birdwatching in their backyard (Tirtaningtyas 2020).

3/26/2021 1:08:00 PMAdaptation to work and school from home has also increased during lockdown and this is a challenge for several biological courses that still need field 
practice (Corlett et al. 2020). Teaching and field practice are moved online and therefore need to be adjusted. During regular courses, field practice is usually conducted by taking students to field sites with lecturer provide direct instructions which are now impossible due to lockdowns. Field practice is crucial in biological fields. The only available option is conducting field practice individually in their own backyards or neighborhood with remote instructions, which may potentially enhance the citizenscience. Tsujimoto (2019) adapted the citizen-science method to involve students in community ecology research and suggested that inexperienced observers can contribute to citizen-science. In ecological studies, citizen-science is commonly used for species occurrence and distribution studies (Bonney et al. 2009; Silvertown 2009; Wei et al. 2016). One of the advantages of citizen-science is to support the lack of data from under-surveyed areas such as private backyard or home gardens (Smith and Hamed 2020). Therefore, in this study, we evaluate how students' field practice can contribute to citizen-science as well as enhancing field practice during online courses. Specifically, we looked at patterns of birds detected around in urban areas and compare the field survey conducted by formal bird survey and students registered in ornithology class.

\section{MATERIALS AND METHODS}

\section{Study area}

We carried out the survey during September-December 2020. There were two sets of data used, the first dataset was the urban bird survey carried out in Depok, a city next to Jakarta involving 4 birdwatchers to collect the data during November-December 2020. The urban bird surveys were focused on three subdistricts in Depok, Indonesia (Beji, Beji Timur, and Kukusan). The other set of data was from students registered in Ornithology class (39 students) which was conducted online during September-December 2020 covering the area where the student lives (Jakarta and West Java-Bekasi, Depok, Bogor) (Figure 1). Some of the birdwatchers were from the same university (Department of Biology, Faculty of Mathematics and Natural Sciences, Universitas Indonesia) which also joined the Ornithology class. Henceforth, the first dataset was called "student surveys" and the second dataset was called "urban bird surveys". We divided the areas into three habitat types, residential, green spaces, and roadside. Residential was housing complex with or without home gardens. Green spaces were considered as all areas destined for parks, including public and residential parks, cemetery, and fishing areas. Roadside included main roads and small roads with at least one lane for each direction (Jaeger et al. 2005).

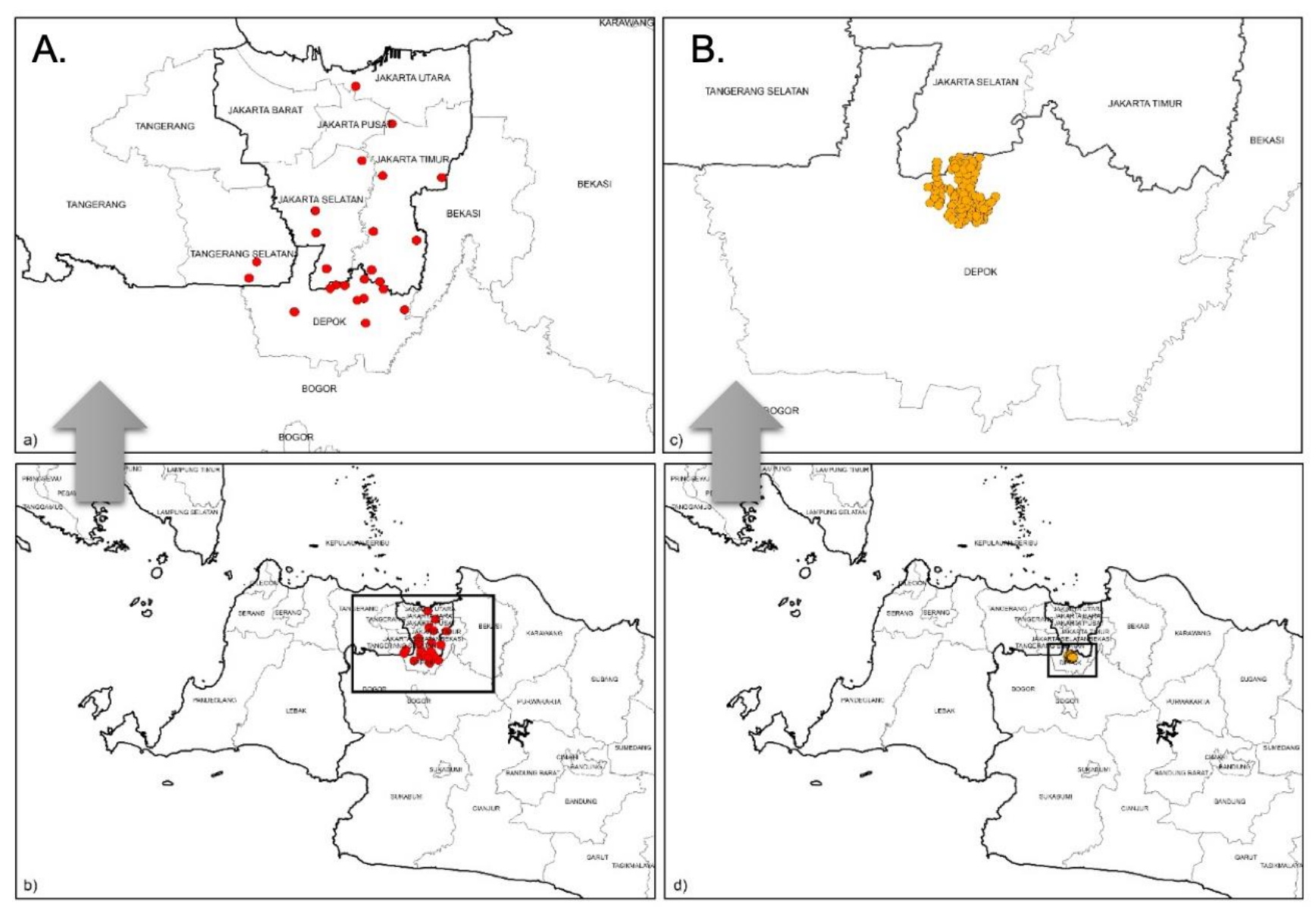

Figure 1. Survey points from 2 datasets. A. Dataset 1 includes an Ornithology class survey around Jakarta, Depok, Bekasi, and Bogor. B Dataset 2 includes urban bird survey conducted in Depok, West Java 


\section{Procedures}

Bird Surveys

We used point count distance sampling for the bird survey where observers stand on a point and record all the birds heard and seen for 5-10 minutes from 06: 00 - 11: 00 (Bibby et al. 2000). For the urban bird surveys, observers walked randomly within the three subdistricts in Depok and carried out point counts at different locations. For the student surveys, students were required to submit three observations from three different survey points either in their backyard or surrounding areas (green spaces and roadside). Students were equipped with "Checklist Burung Kota”, a pictorial leaflet of Birds Around Us by Burung Indonesia (Burung Indonesia 2013). We use ODK Collect, an open-source Android-based application to collect data (Open Data Kit 2018). The use of this application is to ensure that everybody who joined the survey uses the same form and all data is saved immediately after observation on google drive. The tool also allows observer to record geographical locations of the observations (Nowak et al. 2020). The first and the second dataset used different forms with similar variables.

\section{Data analysis}

We assigned species attributes based on their urban tolerance, i.e., urban exploiter and urban adapters (Mardiastuti et al. 2020a), size (small to medium), encounter rate which was calculated based on percentage of records $($ common $=>10 \%$, frequent $=1-10 \%$, occasional $=$
$<1 \%$ ), strata (ground, shrubs, trees, aerial), and detections (species detected by one survey, species detected in both surveys). We used Principal Component Analysis to look at overall patterns of birds detected. Then, we used hierarchical cluster analysis using Euclidean method to compare bird species recorded by student surveys and urban bird surveys to look at differences of birds observed.

\section{RESULTS AND DISCUSSION}

\section{Results}

In total we recorded 18 species with the student surveys recorded 12 species, while the birdwatcher surveys (urban surveys) recorded 15 species. Total number of points visited by students and birdwatchers were 72 and 115 respectively (Table 1). Because more points conducted in residential areas, obviously there were more species recorded in these areas compare to green spaces and roadside with 17 species in total (Table 1, Table 2). The most common species in both surveys were Cave swiftlet (Collocalia linchi) and Eurasian tree sparrow (Passer montanus). By looking only from overall survey points in residentials, the students recorded $83.6 \%$ of Eurasian tree sparrow and $39.3 \%$ cave swiftlets in residential while the urban survey recorded $61.5 \%$ and $84.6 \%$ respectively (Figure 2, Table 2).

Table 1. Survey efforts and number of species recorded

\begin{tabular}{|c|c|c|c|c|c|c|}
\hline & \multicolumn{3}{|c|}{ Student survey } & \multicolumn{3}{|c|}{ Urban bird survey } \\
\hline & Residential & Green spaces & Roadside & Residential & Green spaces & Roadside \\
\hline Total species & & 12 & & & 15 & \\
\hline Number of points & 61 & 7 & 4 & 52 & 19 & 44 \\
\hline Number of species & 12 & 3 & 4 & 14 & 9 & 10 \\
\hline
\end{tabular}

Table 2. Number of bird records from student survey and urban bird survey

\begin{tabular}{|c|c|c|c|c|c|c|c|}
\hline \multirow[b]{2}{*}{ Species } & \multirow[b]{2}{*}{ English name } & \multicolumn{3}{|c|}{ Student survey } & \multicolumn{3}{|c|}{ Urban survey } \\
\hline & & Residential & $\begin{array}{c}\text { Green } \\
\text { spaces }\end{array}$ & $\begin{array}{l}\text { Road- } \\
\text { side }\end{array}$ & Residential & $\begin{array}{r}\text { Green } \\
\text { spaces }\end{array}$ & $\begin{array}{c}\text { Road- } \\
\text { side }\end{array}$ \\
\hline Apus affinis & Little swift & 4 & & & & & \\
\hline Cacomanthis merulinus & Plaintive cuckoo & 5 & & & & & \\
\hline Chalcoparia singalensis & Ruby-cheeked sunbird & 2 & & & & & \\
\hline Collocalia linchi & Cave swiftlet & 24 & 7 & 1 & 44 & 18 & 39 \\
\hline Cynnyris jugularis & Olive-backed sunbird & 3 & & & 8 & 1 & 2 \\
\hline Dendrocopos macei & Fulvous-breasted woodpecker & & & & 1 & & \\
\hline Dicaeum trochileum & Scarlet-headed flowerpecker & 4 & 3 & & 17 & 10 & 19 \\
\hline Hirundo tahitica & Pacific swallow & 3 & & & 18 & 5 & 11 \\
\hline Lanius schach & Long-tailed shrike & & & & 1 & & \\
\hline Lonchura leucogastroides & Javan munia & & & & 1 & & \\
\hline Lonchura maja & White-headed munia & & & & 2 & & 2 \\
\hline Lonchura punctulata & Scaly-breasted munia & & & & & 5 & 1 \\
\hline Orthotomus sutorius & Common tailorbird & & & & 3 & & \\
\hline Passer montanus & Eurasian tree sparrow & 51 & 7 & 4 & 32 & 12 & 27 \\
\hline Prinia familiaris & Bar-winged prinia & 1 & & & 1 & & 1 \\
\hline Pycnonotus aurigaster & Sooty-headed bulbul & 9 & & 1 & 31 & 9 & 26 \\
\hline Pycnonotus goiavier & Yellow-vented bulbul & 3 & & 1 & 16 & 7 & 20 \\
\hline Spilophelia chinensis & Spotted dove & 5 & & & 4 & 3 & \\
\hline
\end{tabular}



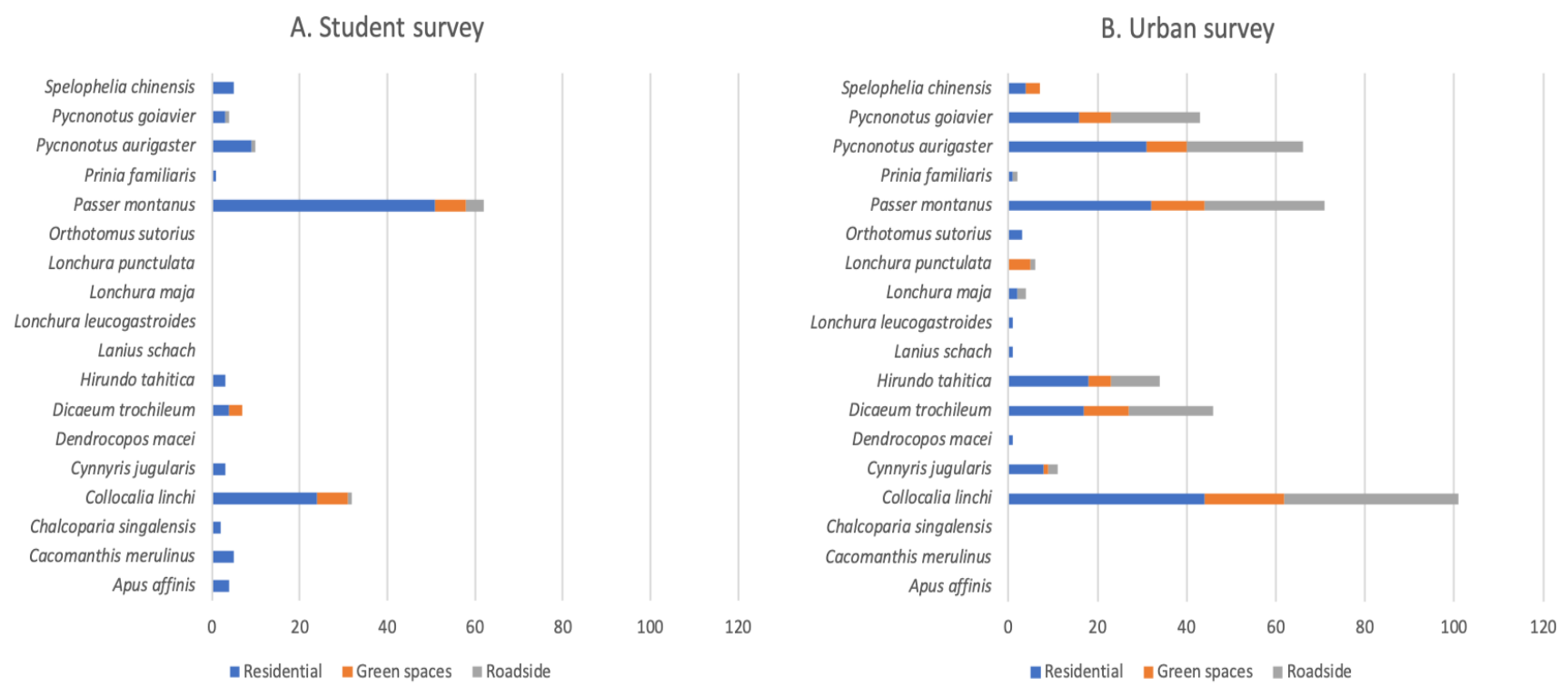

Figure 2. Number of bird recorded at different habitat types

Table 3. Attributes of species recorded during surveys

\begin{tabular}{|c|c|c|c|c|c|c|}
\hline \multirow{2}{*}{ Species } & \multirow{2}{*}{ Urban tolerance } & \multirow{2}{*}{ Size } & \multirow{2}{*}{ Encounters } & \multirow{2}{*}{ Stratum } & \multicolumn{2}{|c|}{ Number of observation } \\
\hline & & & & & Student survey & Urban bird survey \\
\hline Apus affinis & Adapters & Small & Frequent & Aerial & 10 & 0 \\
\hline Cacomanthis merulinus & Adapters & Medium & Occasional & Trees & 5 & 0 \\
\hline Chalcoparia singalensis & Adapters & Small & Occasional & Trees & 2 & 0 \\
\hline Collocalia linchi & Exploiter & Small & Common & Aerial & 96 & 199 \\
\hline Cinnyris jugularis & Exploiter & Small & Frequent & Trees & 3 & 14 \\
\hline Dendrocopos macei & Adapters & Small & Occasional & Trees & 0 & 4 \\
\hline Dicaeum trochileum & Exploiter & Small & Frequent & Trees & 10 & 64 \\
\hline Hirundo tahitica & Adapters & Small & Frequent & Aerial & 4 & 44 \\
\hline Lanius schach & Adapters & Medium & Occasional & Shrubs & 0 & 1 \\
\hline Lonchura leucogastroides & Adapters & Small & Occasional & Shrubs & 0 & 1 \\
\hline Lonchura maja & Adapters & Small & Occasional & Shrubs & 0 & 4 \\
\hline Lonchura punctulata & Adapters & Small & Occasional & Shrubs & 0 & 8 \\
\hline Orthotomus sutorius & Adapters & Small & Occasional & Shrubs & 0 & 6 \\
\hline Passer montanus & Exploiter & small & Common & Ground & 91 & 135 \\
\hline Prinia familiaris & Adapters & small & Occasional & Shrubs & 1 & 3 \\
\hline Pycnonotus aurigaster & Exploiter & medium & Common & Trees & 21 & 106 \\
\hline Pycnonotus goiavier & Adapters & medium & Frequent & Trees & 5 & 63 \\
\hline Spilophelia chinensis & Exploiter & medium & Occasional & Ground & 5 & 8 \\
\hline
\end{tabular}

In the student survey, other birds than the two most common species were detected at low records (Figure 2). Birds that were recorded in student surveys but not in urban bird surveys include Little swift (Apus affinis), Plaintive cuckoo (Cacomanthis merulinus), and Ruby-cheeked sunbird (Chalcoparia singalensis). On the contrary, 6 species were recorded only during urban bird survey, i.e., Fulvous-breasted woodpecker (Dendrocopos macei), Longtailed shrike (Lanius schach), Javan munia (Lonchura leucogastroides), Scaly-breasted munia (Lonchura punctulata), White-headed munia (Lonchura maja), and Common tailorbird (Orthotomus sutorius) (Table 2).
In overall, there were 6 urban exploiters, Cave swiftlet (C. linchi), Eurasian tree sparrow (P. montanus), Sootyheaded bulbul (Pycnonotus aurigaster), Scarlet-headed flowerpecker (Dicaeum trochileum), Olive-backed sunbird (Cinnyris jugularis), and Spotted dove (Spilophelia chinensis). The rests were urban adapters. Birds recorded mostly composed of small species (13 species). Based on percentage of encounters, 3 species were common, 5 species were frequent, and the rests were occasional species (10 species) (Table 3).

The PCA analysis suggested that PC1 explains $60.4 \%$ of variations, while PC2 explains $17.3 \%$ of variations resulting in cumulative proportions of $77.7 \%$. Birds 
recorded were described by the encounter rates in residence, green spaces, and roadside (PC1), and then by stratum and size in which birds with larger size tend to use lower stratum (PC2) (Table 4, Figure 3).

The dendrogram of the cluster analysis suggested that in the student and urban surveys, two species, the cave swiftlet and the Eurasian tree sparrow were both in one cluster suggesting that the two groups can easily detect the two most common, urban exploiter species. However, the rest of clusters were quite different in the two datasets (Figure 4).
Table 4. PCA Results

\begin{tabular}{lcc}
\hline & PC1 & PC2 \\
\hline Eigenvalue & 4.230 & 1.213 \\
Factoriance & 60.435 & 17.322 \\
Urban tolerance & & \\
Size & -0.364 & 0.325 \\
Encounter & -0.021 & -0.629 \\
Strata & 0.448 & 0.087 \\
Observations in residential & 0.106 & 0.700 \\
Observations in greenspaces & 0.470 & 0.012 \\
Observations in roadside & 0.457 & 0.003 \\
\hline
\end{tabular}

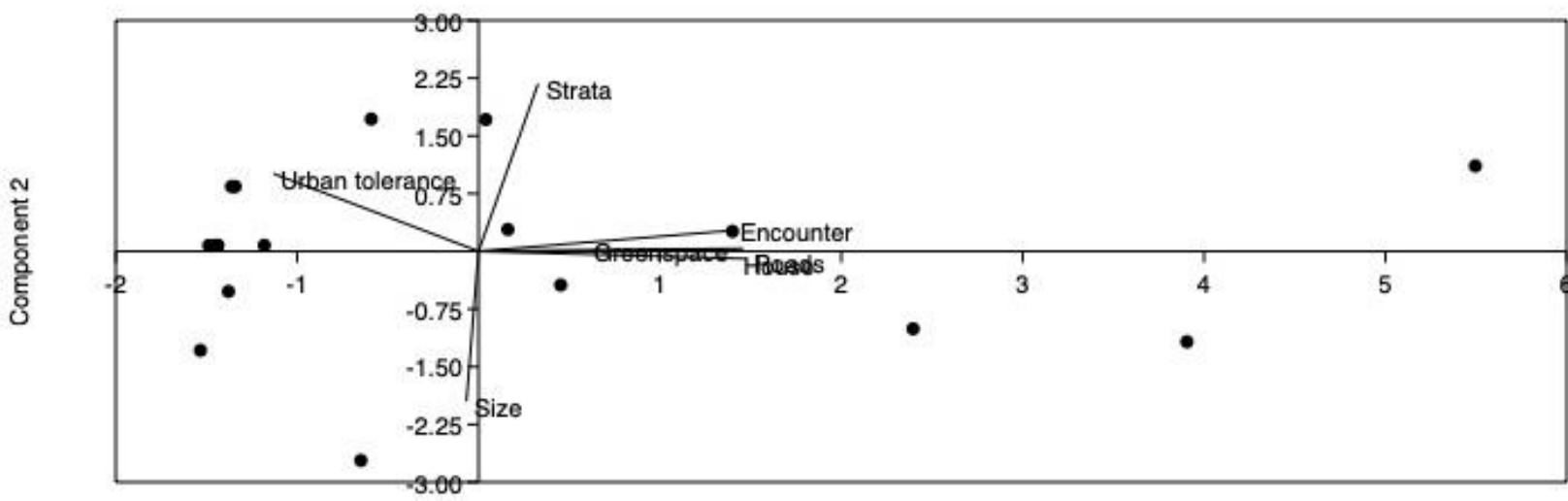

Component 1

Figure 3. Principal Component Analysis with PC1 and PC2

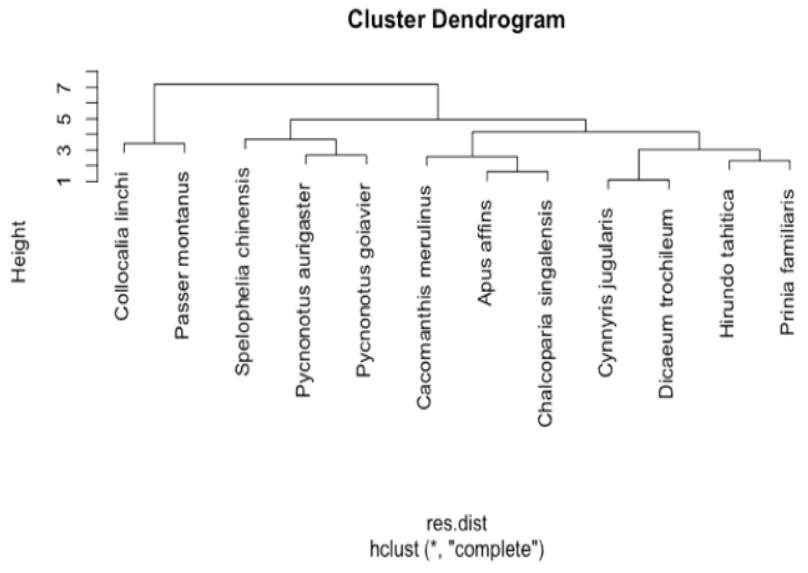

A. Student survey

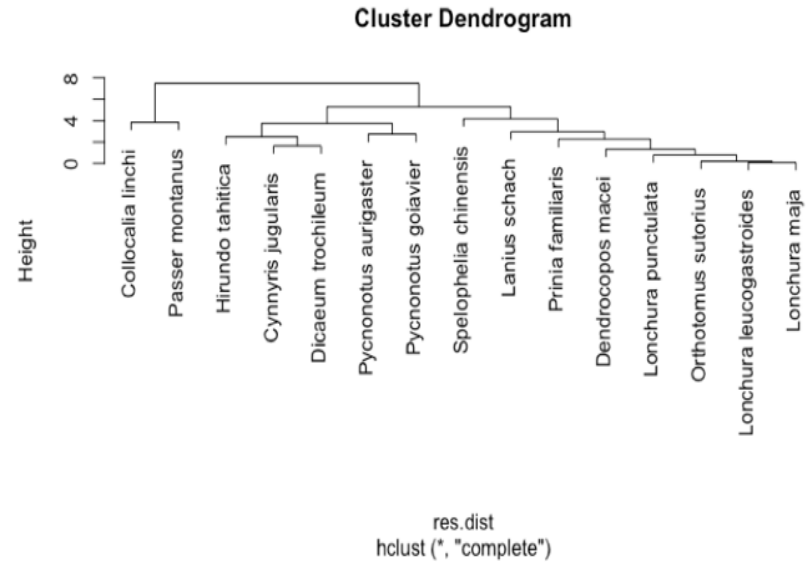

B. Urban survey

Figure 4. Dendrogram from two different surveys 


\section{Discussion}

Detections of urban bird community

This study suggested that both student's surveys and formal urban bird surveys were able to detect common birds in the urban areas. However, we recognized that the sample size may be too small to provide a complete picture of urban communities. All bird species we observed during our research were urban exploiters and adapters. Thus, our study area's urban bird community is most probably the same as the bird community before the COVID 19 pandemic started (Mardiastuti et al. 2020a).

Residential garden is potential to support urban wildlife including birds and ecosystem services for the resident's well-being (Yan et al. 2020). Residential particularly in Indonesia is usually accompanied by home gardens planted by various trees and crops (Kumar and Nair 2004; Yan et al. 2020). Residential, therefore provide easy and accessible areas for urban bird survey. Residential and surrounding areas offer habitat for urban exploiters and adapters (Blair 1996; Mardiastuti et al. 2020a,b). At least two species, $P$. montanus and $C$. linchi were the most common urban exploiters which are able to utilize humandominated areas and usually present at highest density (Blair 1996; Mardiastuti et al. 2020a). The overall bird community patterns from the two surveys suggested that bird abundance in urban areas were the most important attributes in the detections particularly for students. As urban exploiter, $C$. linchi and $P$. montanus are able to exploit buildings and houses to build nests (Zhang and Zheng 2010; Nor et al. 2017). The two species were the most common and at least consistently detected by both students and urban surveys in more than $30 \%$ of overall points within the residential.

The second most important attributes were size and stratum. Aerial insectivores and graminivores tend to survive in urban areas, as well as those with canopy nest sites (Conole and Kirkpatrick 2011; Corlett et al. 2020). Smaller birds such as C. linchi, Hirundo tahitica which are aerial birds tend to use the highest stratum, while mediumsized birds tend to use the trees to the ground such as the Spilophelia chinensis. Although S. chinensis is able to fly across different areas, the birds were usually detected foraging on the ground (MacKinnon and Phillipps 1993). Other than the two most common species, Pycnonotus aurigaster, Dicaeum trochileum, Cynniris jugularis, and $P$. goiavier were also quite common and frequent residents of urban areas (Pradana et al. 2019; Mardiastuti et al. 2020a,b) such as residentials, green spaces, and even roadside. However, these species were inconsistently detected by students compare to urban surveys.

Bias and inconsistency in data collections usually occurred in citizen science particularly due to observer heterogeneity (Burgess et al. 2017; van der Velde et al. 2017; Tsujimoto et al. 2019). One of the challenges in conducting online biological classes was particularly in providing training on field observations due to the lack of interactions. It was hard to standardize observers particularly students who never have experience in birdwatching. Detecting targets are essential in wildlife survey and is common problem in-field training (Supriatna et al. 2020). There was tendency for the students to observe easy-abundant targets such as the Eurasian tree sparrows or cave swiftlet which are common in the urban areas, but less on unfamiliar species which use vegetation. Failure to detect unknown species is common in citizen science projects and care should be taken when interpreting results (Faanes and Bystrak 1981). However, when prioritizing the most common abundant species which are easy to identify, students can also support citizen science projects and contribute to urban research. The fact that urban research in Asia was considered the lowest suggested the importance of citizen science projects, adding data from residential home gardens (Magle et al. 2012). Residential home gardens can be considered as under-surveyed areas with the advantage of not requiring special permission (Smith and Hamed 2020). Involving students in science projects is also giving them their first career experience in research (Tsujimoto et al. 2019).

\section{Field practice during pandemic, a lesson-learned}

The pandemic situations created a wide-spread change in teaching and learning processes (Lashley et al. 2020) which particularly affected field-based courses such as ecology, evolution, and conservation biology (Corlett et al. 2020). Almost without preparation, online biological courses during pandemic starting early 2020 have been brought a great challenge to both the lecturers and students. Changing teaching techniques are needed to enhance learning process (Jenkins 2011). Biological online courses are usually embraced both field practice and teaching, therefore should be adaptive, innovative, and consider internet access and costs (Purwanto et al. 2020).

Fieldworks during pandemic should be adjusted with local regulations in social distancing restrictions related to COVID-19. For example, fieldwork should enable less contact among observers and the people in the target areas. When conducted in urban areas, wearing a mask is compulsory. Some best practices for conducting online field practice are as follows:

(i) Create field practice that enable students to work independently. Providing remote instructions and field guides when observing wildlife is necessary and will help students to be able to identify the species correctly. Remote instructions must be clear and concise. There are also online participatory science platforms such as iNaturalist or Burungnesia which is publicly available, can also be used for students to conduct remote field observations (Winnasis et al. 2018; Gerhart et al. 2020; Unger et al. 2020).

(ii) Evaluate technology affordances and apply them during field practice (Kaviani et al. 2020). In this study, we use apps to enable observers to collect data which lecturers can check the results right away. The ODK Collect used in this study provided geographical locations (Open Data Kit 2018) which are useful to map the bird distributions in urban areas, and can be overlaid with forest cover, etc., when needed for subsequent analysis (Anokwa et al. 2009). ODK Collect is particularly available for android users 
which should be taken into account when mobilizing students.

(iii) Always show and discuss the results of the survey to students and get feedback. This would enable students to understand the concept of field observations, the challenge, and difficulties, as well as see the results and making conclusions. Clarification on the data can also be communicated to avoid any misunderstanding in the data collection.

Corlett et al. (2020) suggested that conservation is supposed to go forward and depends on work in the field. He suggested possible examples of research questions to enhance research and conservation such as focusing on impact of pandemic situations to wildlife population and ecosystem. Examples of research questions to education, training, and networking such as impact of pandemic situations on learning outcomes, career impacts and the development of online technology (Corlett et al. 2020). Strengthening field practice for biological courses is therefore essential to support biodiversity conservation research and activities. Although the results might be less than ideal, we must continue to explore the development of field practice associated with biological courses.

\section{ACKNOWLEDGEMENTS}

Part of this study particularly the urban bird survey was funded through the Universitas Indonesia funding Hibah PUTI Q3 (NKB-1967/UN2.RST/HKP.05.00/2020). We thank all the students in Ornithology class 2020 of the Department of Biology, Faculty of Mathematics and Natural Sciences, Universitas Indonesia. Finally, we thank the reviewers for their comments on an earlier version of the manuscript.

\section{REFERENCES}

Anokwa Y, Hartung C, Brunette W, Borriello G, Lerer A. 2009. Opensource data collection in the developing world. Computer 42 (10): $97-$ 99. DOI: 10.1109/MC.2009.328.

Bibby CJ, Burgess ND, Hill DA, Mustoe SH. 2000. Bird Census Technique. Second Edition. Academic Press, London.

Blair RB. 1996. Land use and avian species diversity along an urban gradient. Ecol Appl 6 (2): 506-519. DOI: 10.2307/2269387.

Bonney R, Cooper CB, Dickinson J, Kelling S, Phillips T, Rosenberg KV, Shirk J. 2009. Citizen science: A developing tool for expanding science knowledge and scientific literacy. BioScience 59 (11): 977 984. DOI: 10.1525/bio.2009.59.11.9.

Burgess HK, DeBey LB, Froehlich HE, Schmidt N, Theobald EJ, Ettinger AK, HilleRisLambers J, Tewksbury J, Parrish JK. 2017. The science of citizen science: Exploring barriers to use as a primary research tool. Biol Conserv 208: 113-120. DOI: 10.1016/j.biocon.2016.05.014.

Burung Indonesia. 2013. Checklist Burung Kota. Birds Around Us. Burung Indonesia, Bogor.

Conole LE, Kirkpatrick JB. 2011. Functional and spatial differentiation of urban bird assemblages at the landscape scale. Landsc Urban Plan 100: 11-23. DOI: 10.1016/j.landurbplan.2010.11.007.

Corlett RT, Primack RB, Devictor V, Maas B, Goswami VR, Bates AE, Koh LP, Regan TJ, Loyola R, Pakeman RJ. 2020. Impacts of the coronavirus pandemic on biodiversity conservation. Biol Conserv 246: 108571. DOI: 10.1016\%2Fj.biocon.2020.108571.

Derryberry EP, Phillips JN, Derryberry GE, Blum MJ, Luther D. 2020. Singing in a silent spring: Birds respond to a half-century soundscape reversion during the COVID-19 shutdown. Science 370 (6516): 575579. DOI: $10.1126 /$ science.abd5777.

Faanes CA, Bystrak D. 1981. The role of observer bias in the North American breeding bird survey. Stud Avian Biol 6: 353-359.

Gerhart L, Jadallah C, Angulo S, Ira G. 2020. Teaching an experiential field course via online participatory science projects: A COVID-19 case study of a UC California Naturalist Course. Authorea. DOI: 10.22541/au.159363314.47548916.

Jaeger JA, Bowman J, Brennan J, Fahrig L, Bert D, Bouchard J, Charbonneau N, Frank K, Gruber B, von Toschanowitz KT. 2005. Predicting when animal populations are at risk from roads: An interactive model of road avoidance behavior. Ecol Model 185: 329348. DOI: 10.1016/j.ecolmodel.2004.12.015.

Jenkins LL. 2011. Using citizen science beyond teaching science content: A strategy for making science relevant to students' lives. Cult Stud Sci Educ 6 (2): 501-508. DOI: 10.1007/s11422-010-9304-4.

Kaviani A, Tamim R, Ghaemi H. 2020. Teaching and learning during a global pandemic: An ecological approach. Modern Journal of Language Teaching Methods (MJLTM) 10 (8): 1-8. DOI: 10.26655/mjltm.2020.8.1.

Kumar BM, Nair PR. 2004. The enigma of tropical home gardens. Agrofor Syst 61: 135-152. DOI: 10.1023/B: AGFO.0000028995.13227.ca.

Lashley MA, Acevedo M, Cotner S, Lortie CJ. 2020. How the ecology and evolution of the COVID-19 pandemic changed learning. Ecol Evol 10: 12412-12417 DOI: 10.1002/ece3.6937.

MacKinnon J, Phillipps K. 1993. A Field Guide to the Birds of Borneo, Sumatra, Java, and Bali. Oxford University Press, New York.

Magle SB, Hunt VM, Vernon M, Crooks KR. 2012. Urban wildlife research: Past, present, and future. Biol conserv 155: 23-32. DOI: 10.1016/j.biocon.2012.06.018.

Mardiastuti A, Mulyani YA, Rinaldi D, Rumblat W, Dewi LK, Kaban A, Sastranegara H. 2020. Synurbic avian species in Greater Jakarta Area, Indonesia. IOP Conf Ser Earth Environ Sci 457 (1): 012001. DOI: 10.1088/1755-1315/457/1/012001.

Mardiastuti A, Putra MSK, Mulyani YA. 2020. Bird diversity patterns along urbanization gradients: Some recommendations for landscape planners. IOP Conf Ser Earth Environ Sci 556: 012-012. DOI: 10.1088/1755-1315/556/1/012012.

Murawiec S, Tryjanowski P. 2020. A psychiatrist watches birds during the COVID-19 pandemic: Observations, introspections, interpretations. Psychiatr Psychol Klin 20: 94-97. DOI: 10.15557/PiPK.2020.0012.

Myers KR, Tham WY, Yin Y, Cohodes N, Thursby JG, Thursby MC, Schiffer P, Walsh JT, Lakhani KR, Wang D. 2020. Unequal effects of the COVID-19 pandemic on scientists. Nat Hum Behav 4 (9): 880883. DOI: $10.1038 / \mathrm{s} 41562-020-0921-\mathrm{y}$.

Nor ANM, Corstanje R, Harris JA, Brewer T. 2017. Impact of rapid urban expansion on green space structure. Ecol Indic 81: 274-284. DOI: 10.1016/j.ecolind.2017.05.031.

Nowak MM, Dziób K, Ludwisiak L, Chmiel J. 2020. Mobile GIS applications for environmental field surveys: A state of the art. Glob Ecol Conserv 23 (1): e01089. DOI: 10.1016/j.gecco.2020.e01089.

Open Data Kit. 2018. Open Data Kit Documentation (2017).

Pradana DH, Mardiastuti A, Yasman Y. 2019. Utilization of Ficus benjamina by birds at urban habitat in Depok. Bioma 20 (1): 75-78. DOI: 10.14710/bioma.20.1.75-78.

Pramana S, Paramartha DY, Adhinugroho Y, Nurmalasari M. 2020. Air pollution changes of Jakarta, Banten, and West Java, Indonesia during the first month of COVID-19 pandemic. J Bus Econ Environ Stud (JBEES) 10 (4): 15-19. DOI: 10.13106/jbees.2020.vol10.no4.15.

Purwanto A, Asbari M, Fahlevi M, Mufid A, Agistiawati E, Cahyono Y, Suryani P. 2020. Impact of Work From Home (WFH) on Indonesian teachers performance during the Covid-19 pandemic: An exploratory study. Intl J Adv Sci Technol 29 (5): 6235-6244.

Randler C, Tryjanowski P, Jokimäki J, Kaisanlahti-Jokimäki M-L, Staller N. 2020. SARS-CoV2 (COVID-19) pandemic lockdown influences nature-based recreational activity: The case of birders. Intl J Environ Res Public Health 17 (19): 7310. DOI: 10.3390/ijerph17197310.

Silvertown J. 2009. A new dawn for citizen science. Trends Ecol Evol 24 (9): 467-471. DOI: 10.1016/j.tree.2009.03.017.

Smith WH, Hamed MK. 2020. Trade-offs in moving citizen-based anuran call surveys online during the SARS-CoV-2 pandemic: Lessons from rural Appalachia, USA. Ecol Evol 10 (22): 12465-12471. DOI: $10.1002 \% 2$ Fece 3.6654 .

Stokstad E. 2020. Pandemic lockdown stirs up ecological research. Science 369: 893. DOI: 10.1126/science.369.6506.893. 
Supriatna J, Leo S, Anugra BG, Dwiyahreni AA, Winarni NL, Margules C. 2020. Lessons learned from training students to conduct primate surveys. Primate Conserv 34: 217-225.

Tirtaningtyas FN. 2020. Kreatifnya Kaysan, Remaja Penggagas Amati Burung di Sekitar Rumah. //www.mongabay.co.id/2020/09/26/kreatifnya-kaysan-remajapenggagas-amati-burung-di-sekitar-rumah/. [25 February 2021]. [Indonesian]

Tsujimoto D, Lin C-H, Kurihara N, Barnett CR. 2019. Citizen science in the class-room: The consistency of student collected data and its value in ecological hypothesis testing. Ornithol Sci 18 (1): 39-47. DOI: 10.2326/osj.18.39.

Unger S, Rollins M, Tietz A, Dumais H. 2020. iNaturalist as an engaging tool for identifying organisms in outdoor activities. J Biol Educ. DOI: 10.1080/00219266.2020.1739114.

van der Velde T, Milton DA, Lawson TJ, Wilcox C, Lansdell M, Davis G, Perkins G, Hardesty BD. 2017. Comparison of marine debris data collected by researchers and citizen scientists: Is citizen science data worth the effort? Biol Conserv 208: 127-138. DOI: 10.1016/j.biocon.2016.05.025.

Wei JW, Lee BPY, Bing Wen L. 2016. Citizen science and the urban ecology of birds and butterflies - a systematic review. PLoS ONE. 11 (6): e0156425. DOI: 10.1371/journal.pone.0156425.

Winnasis S, Hakim L, Imron MA. 2018. The utilization of burungnesia to detect citizen scientist participation preference in birding sites observation in Java Island. J Indon Tour Dev Stud 6 (1): 49-54. DOI: 10.21776/ub.jitode.2018.006.01.07.

Yan J, Zhou W, Zheng Z, Wang J, Tian Y. 2020. Characterizing variations of greenspace landscapes in relation to neighborhood characteristics in urban residential areas of Beijing, China. Landsc Ecol 35 (1): 203222. DOI: $10.1007 / \mathrm{s} 10980-019-00943-3$.

Zhang S, Zheng G. 2010. Effect of urbanization on the abundance and distribution of Tree sparrows (Passer montanus) in Beijing. Chin Birds 1 (3): 188-197. DOI: 10.5122/cbirds.2010.0012. 